\title{
Application of Waste Banana PEels as BIODEGRADABLE PLASTIC
}

\begin{abstract}
Nur Athirah Huzaisham
Department of Mechanical Engineering Technology, Faculty of Engineering Technology, Universiti Tun Hussein Onn Malaysia (UTHM)

Malaysia

Noraini Marsi*

Department of Mechanical Engineering Technology, Faculty of Engineering Technology, Universiti Tun Hussein Onn Malaysia (UTHM)

Malaysia

\section{Muhamad Haikal Mohd Fodzi}

Department of Mechanical Engineering Technology, Faculty of Engineering Technology, Universiti Tun Hussein Onn Malaysia (UTHM)

Malaysia

\section{Rupashinii A/P Thana Singam}

Department of Mechanical Engineering Technology, Faculty of Engineering Technology, Universiti Tun Hussein Onn Malaysia (UTHM)

Malaysia
\end{abstract}

*Corresponding author's Email: mnoraini@uthm.edu.my

Peer-review under responsibility of $3^{\text {rd }}$ Asia International Multidisciplanry Conference 2019 editorial board

(http://www.utm.my/asia/our-team/)

(C) 2019 Published by Readers Insight Publisher,

lat 306 Savoy Residencia, Block 3 F11/1,44000 Islamabad. Pakistan,

info@readersinsight.net

This is an open access article under the CC BY-NC-ND license (http://creativecommons.org/licenses/by-nc-nd/4.0/). 


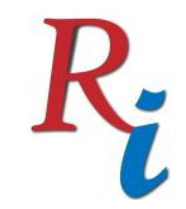

\section{Science Proceedings Series (SPS) \\ www.readersinsight.net/SPS}

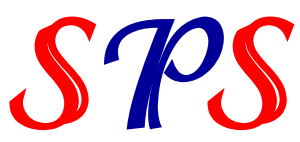

\section{R E S E A R C H H I G H L I G H T S}

The world today seems unimaginable without plastics or synthetic organic polymer, however their large-scale production and use only dates back to 1950 (1). The resulting rapid growth in plastics production is remarkable, surpassing most other man-made materials. The study presents the utilization of banana peel as biodegradable plastic to substitute the existing nonbiodegradable plastic. The objectives of this research are to aims to develop and produce biodegradable plastic that will substitute the existing non-biodegradable plastic to help in saving the environment as well as to compare the properties of biodegradable plastic based on banana peel with the commercial biodegradable plastic. The use of waste banana peel in this study is mainly to replace the synthetic materials used in the conventional biodegradable plastic. Furthermore, the environmental pollutions can be reduced due to the usage of waste banana peels to produce a new value-added biodegradable plastic.

Keywords: Banana Peel, Biodegradable Plastic, Pollution, Environment

\section{RESEARCH OBJECTIVES}

It is likely that in the future, the plastic materials we will use would be very different from those used today. The demand by the societies and environment for more 'greener' materials has brought on innovations in the plastic industry to develop new polymers that are derived from renewable biological resources and also polymers that are conceived as biodegradable (2).The usage of biodegradable plastic can help in reducing the dependency on petroleum that involved in the process of plastic-making and also helps in reducing pollution caused by burning and waste of plastics in the sea or soil (3). The motivation for the development of biodegradable plastics is that they will easily disintegrate and biodegrade when inadvertently emitted to the environment (4).Therefore, this study aims to develop and produce biodegradable plastic that will substitute the existing non-biodegradable plastic to help in saving the environment.

\section{MATERIALS AND METHODS}

In this study, the fabrication of samples involved several stages where banana peels were separated from the chaff and were chopped into smaller pieces. Then, the peels were grinded and blended until they became delicate and later was mixed with tapioca starch with four different concentration of banana peel which are $20 \%, 40 \%, 60 \%$ and $80 \%$. The mixture was then poured into a mould and was left under sunlight to dry. A few tests were conducted to evaluate the mechanical and physical properties of the biodegradable plastic.

\section{RESULTS}

Degradation and tensile strength test were conducted to analyse the relationship between different concentration of waste banana peel and its mechanical properties. The degradation test was carried out according to standard method ASTM D5988-18. Based on the results related to degradability of the plastic, this study discovers that all of the samples showed the ability to degrade where as the concentration of waste banana peels increases, the degradability of the plastic also increases. The samples slowly decreased in sizes with time and showed clear evidences of degradation with the growth of fungus and disintegration within 5 week (5). According to the findings from the tensile strength test, this study notices that the strength increases with the increasing percentage of tapioca starch ranging from $23.7 \mathrm{Mpa}$ up to 39.3 


\section{$R_{i}$}

\section{Science Proceedings Series (SPS) \\ www.readersinsight.net/SPS}

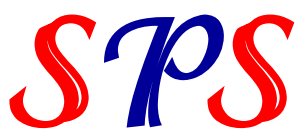

Mpa where sample with $80 \%$ concentration of banana peels exhibited the highest tensile strength.

\section{FINDINGS}

This research is significant as it brings forth improvements on the properties of biodegradable plastic based on banana peel. This study clearly demonstrated that this biodegradable plastic based on banana peel gives good performance on its mechanical and physical properties. It is found that $80 \%$ concentration of banana peel is the optimum concentration of banana peel due to its robustness and astounding degradability. These findings were considered successful as the plastics are able to show substantial properties that would help with the initiative of "going green" policy.

\section{ACKNOWLEDGEMENT}

The authors would like to thank the Universiti Tun Hussein Onn Malaysia for supporting this project under Contract Grant by UTHM Scheme under Vot H341.

\section{REFERENCES}

1. Shah, A. A., Hasan, F., Hameed, A., \& Ahmed, S. (2008). Biological degradation of plastics: A comprehensive review. Biotechnology Advances, 26(3), 246-265. https://doi.org/10.1016/j.biotechadv.2007.12.005

2. Mostafa, N. A., Farag, A. A., Abo-dief, H. M., \& Tayeb, A. M. (2018). Production of biodegradable plastic from agricultural wastes. Arabian Journal of Chemistry, 11(4), 546-553. https://doi.org/10.1016/j.arabjc.2015.04.008

3. Padam, B. S., Tin, H. S., Chye, F. Y., \& Abdullah, M. I. (2014). Banana by-products: an underutilized renewable food biomass with great potential. Journal of Food Science and Technology, 51(12), 3527-3545. https://doi.org/10.1007/s13197-012-0861-2

4. Agamuthu, P., \& Faizura, P. N. (2005). Biodegradability of degradable plastic waste. Waste Management and Research, 23(2), 95-100. https://doi.org/10.1177/0734242X05051045

5. Sudesh, K., \& Iwata, T. (2008). Sustainability of biobased and biodegradable plastics. Clean Soil, Air, Water, 36(5-6), 433-442. https://doi.org/10.1002/clen.200700183 